\title{
Editorial: Performance Moves
}

\author{
CHARLOTTE M. CANNING
}

One of the most productive contributions to performance that scholars have made to theorizing globalization is to document how people understand global transformation as expressed through representation. An additional element of this contribution is the examination of reception - what understanding did audiences and critics glean from what they saw onstage. This issue of Theatre Research International brings together a diverse set of articles, ones that were not written with any of the others in mind. Despite this, however, read together these articles offer a primer on the effects, successes and failures of performance in the context of global movement currently and in the past. Some of these authors look at theatre that literally travels - around the world, around the nation - and others that travel more figuratively - as part of historical circuits of transmission like colonialism. In whatever sense travel is defined and explored in this issue of TRI, all of these articles remind us that live performance is always about the circulation of embodied ideas through time and space. Travel is built into the form itself.

Nicola Hyland's 'Unsettling Blanket Man: The "Ecological Māori” as a Pākeha PlayThing' is aimed at one of the most troubling tropes of white-settler colonialism - the character of the deeply spiritual indigenous person with profound connection to the earth. The Wellington, New Zealand, BATS Theatre 2013 production of The Road That Wasn't There had a pivotal character based on a local homeless Māori man, Ben Hana, also known as 'Blanket Man'. The inclusion of Hana was intended to recognize Hana's presence in the city, but the choice to embody the character through a puppet, and one animated by a non-Māori performer, doubly marginalized and erased Hana. This was achieved first by representing him as a non-human and then by representing him as homeless - both in the contemporary urban landscape and then as 'unsettled' from Māori lands by centuries of colonialism. In this article Hyland explores in detail the ways in which racism is and can be staged and received. This exploration reminds us that what is intended as a new and empowering representation of the marginalized may simply be, in fact, one of the oldest and most familiar forms of racism.

While TRI is not primarily a journal for historical work, one of the most important discursive challenges any moment faces is how it will construct and debate the past. Such debates may allow us to identify the ways in which settler colonialism continues to inform performance in many parts of the world, or, as in 'The Bandmann Circuit: Theatrical Networks in the First Age of Globalization', it may offer us new ways to understand how theatre is a transnational enterprise. Christopher B. Balme documents the important shift in European theatrical production from the actor-manager to the producer. This move established global networks that allowed European theatre to extend its reach further than ever before. Michel de Certeau argues that history is 'founded on a rupture 
between a past that is its object and a present that is the place of its practice' ${ }^{1}$ In this article we can see the relationships between object and practice, past and present, play out in the work of establishing a past for theatrical globalization. This is a challenge that as much redefines the present as it creates new understandings of theatre's past.

One of the most quotidian and traditional ways that theatre considers the past is through the production of plays from previous historical moments. This is nowhere more true than in productions of Shakespeare, even though those productions may pose singular challenges to our current sense of theatre. Why do we laugh when seeing productions of Shakespeare in some venues and not others? Amy Kenny asks this question in "I Hope 'Twill Make You Laugh": Audience Laughter at The Globe Theatre. Kenny is specifically looking at audiences at the Globe Theatre in London, but her work opens a conversation about audience that is applicable in many places in the world. At the Globe, tourist audiences, much to Guardian theatre critic Michael Billington's frustration, laugh during performances of plays not considered comedies (like Macbeth), or at moments that are not particularly funny. For Kenny, the explanations for this phenomenon can be found in the architecture of the performance space. Lighting, too, has a tremendous impact. Unlike most performance today, the performers and the spectators in the Globe share the same lighting conditions, encouraging a kind of connection between the two that is specific to that space. As in Balme's article, Kenny argues that we cannot understand our contemporary theatre experience without a detailed appreciation of the past conditions that produced that theatre.

Josh Stenberg and Zhang Jinging explore one performance form's transition from state-financing to commercial, self-supporting production. 'Scholar Dong and Madam Li Step Out: Are There National Audiences for Chinese Traditional Regional Theatre?' documents the process that xiqu undergoes as it moves from dependable support to the vagaries of the market. The particular set of choices made by the producers and others are instructive for any performance form that must appeal to the market. In this case, xiqu secured its commercial audience by becoming less of an art that intends to appeal to the 'people', and more one that appeals to, as Stenberg and Zhang put it, a 'highbrow, affluent' audience. The national system for identifying the shows to be promoted, however, is complex and largely closed to public view. The state may be withdrawing funding, but it is not withdrawing control. Productions available to audiences are made so through a complex series of official manoeuvres. As China develops within a global capitalist paradigm, the path of the arts in general and live performance in particular will continue to be a challenge to the circulation and survival of traditional art forms.

The last time TRI included a forum series of articles was in March 2012 on identity politics, with articles by members of the Feminist Working Group of the International Federation for Theatre Research. I am pleased to be able to follow that excellent work with a forum that is contiguous with its predecessor while also reflecting recent developments in the federation. Alyson Campbell and Fintan Walsh introduce and guest-edit this collection of short articles, 'Contemporary Queer Theatre and Performance Research: A Forum by the Queer Futures Working Group', which easily demonstrates the significant work occurring in the working group. The group named itself, as Campbell and Walsh note, to be 'mindful of queer theory's temporal turn', as well as to indicate the 
federation's commitment to queer scholarship. This forum operates as a collective stateof-the-profession document that explores such diverse topics as South African pageants, solo performance, lesbian feminist performance practices, and early twentieth-century Argentinian theatre, to name just a few of the topics covered here. Taken together, the forum demonstrates the vitality and vibrancy of queer research in performance across the globe.

NOTE

$1 \quad$ Michel de Certeau, The Writing of History, trans. Tom Conley (New York: Columbia University Press, 1992), p. 85. 